\title{
Granulometry of pebble beach ridges in Fort Williams Point, Greenwich Island, Antarctic Peninsula; a possible result from Holocene climate fluctuations
}

\author{
E. Santana ${ }^{1}$ and J. F. Dumont ${ }^{2}$ \\ ${ }^{1}$ Instituto Oceanográfico de la Armada (INOCAR), Base Naval Sur, Guayaquil, Ecuador. \\ ${ }^{2}$ ESPOL, La Prosperina, Guayaquil Ecuador, and IRD Géosciences Azur, France.
}

\begin{abstract}
We present a granulometric study of emerged pebble beach ridges in the Fort Williams Point, Greenwich Island, Antarctic Peninsula. We studied 8 beach ridges from the shore up to $13.5 \mathrm{~m}$ above current sea level. The beach ridges are made of volcanic material from the surrounding relief, but also include glacially transported gneiss and granodiorite pebble and cobble. Based on granulometric distribution analysis of 2100 samples from 39 locations we identified evidence of 4 sequences of 1 to 3 ridges. Most of the material seems to be reworked from a till. Pavement formation by iceberg between the sequences of beach ridges suggests periods of lower temperature. The interpretation suggests that sequences of beach ridge construction formed during warmer periods of the late Holocene. This occurs in the framework of an isostatic postglacial uplift allowing the progressive mobilization of periglaciar material.

Citation: Santana, E., and Dumont, J.F. (2007), Granulometry of pebble beach ridges in Fort Williams Point, Greenwich Island, Antarctic Peninsula; a possible result from Holocene climate fluctuations, in Antarctica: A keystone in Changing World - Online Proceedings of the $10^{\text {th }}$ ISAES, edited by A.K.Cooper and C.R. Raymond et al., USGS Open-File Report 2007-1047, Short Research Paper 027, 4 p.; doi:10.3133/of2007-1047.srp027.
\end{abstract}

\section{Introduction}

There are many beach ridges at elevations below 20 $\mathrm{m}$ on the Holocene coastal platforms of the Antarctic Peninsula (Bentley et al., 2005a; Clapperton and Sugden, 1988; John and Sugden, 1971). The oldest post glacial marine occurrences are no older than $6500{ }^{14} \mathrm{C}$ yr BP (Bentley et al., 2005a; Pallas et al., 1997). The relative sea level (RSL) curve is complex, showing a midHolocene highstand of $14.5-16 \mathrm{~m}$ above mean sea level (amsl) and a RSL fall during late Holocene (Bentley et al., 2005a). The coastal morphology considered in this paper fits with this highstand and the following RSL fall. Neotectonic uplift in the Antarctic Peninsula combines with glacio-eustatic adjustment for about $16 \%$ of the total uplift that explains the variation of elevation of the highest marine platforms encountered between 14 and 20 $\mathrm{m}$ amsl (Pallas et al., 1997). A detail analysis of Holocene RSL curves from different parts of the Antarctic Peninsula lead Bentley et al. (2005b) to suggest greater oceanic-atmospheric variability than what is observed in recent decades. This postglacial uplift allows the progressive mobilization of till.

The Chile Bay opens on the English Strait, with the Fort Williams Point (also called Spark Point) at the northwestern corner and the Bascope Point at the southeastern one (Fig. 1). Araya and Hervé (1966) measured the morphological parameters of the pebble beach ridges near Bascope Point, underlying their continuity, spacing, and maximum elevation up to $18 \mathrm{~m}$. Bedrock of Fort Williams Point is constituted by andesites of Late Cretaceous to Paleocene age (Araya and Hervé, 1966; Dumont et al., 2006; Santana and Dumont, 2003; Smellie et al., 1996; Smellie et al., 1984). A sill unit crops out in Fort Williams Point with rocks relatively sensitive to weathering and gelifraction. The coastal platforms show scattered meter size blocks of granodiorites and gneiss, rock types that do not crop out in the area, but are described by Smellie et al., (1984) from the basement of the southwestern part of Greenwich Island. The presence of these blocks suggests a main motion of the glacial ice cover to the NE, what would be in agreement with the main trend of glacial striation observed along the west coast of the Chile Bay below the ice cap.

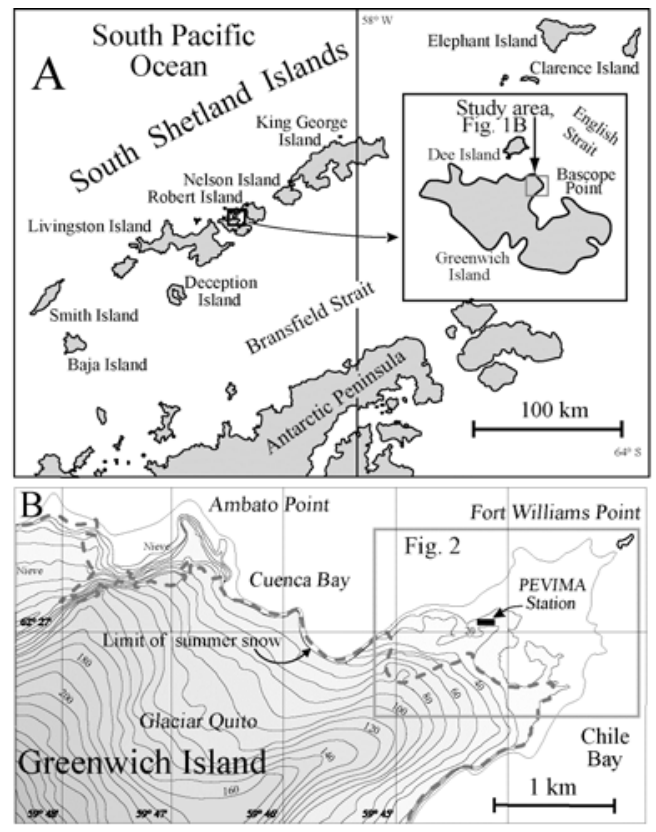

Figure 1. A: Location of Greenwich Island in the South Shetland Islands. B: Topographic map of Fort Williams Point.

Dating of a large (3m observed) whale rib deeply inserted near the top $(4.8 \mathrm{~m}$ amsl) of a beach ridge (point 115, Fig. 2), and $180 \mathrm{~m}$ inland from the present active ridge (Santana and Dumont, 2002) yields $1570 \pm 60{ }^{14} \mathrm{C}$ yr BP. The whalebone may be older than the ridge, but the marine reservoir correction according to Berkman and Foreman (1996) suggests a more recent and even a 
sub-actual deposit. However the context suggests a lower correction of no more than 500-600 yr according to Curl (1980).

We present here a granulometric analysis of the 8 successive pebble beach ridges observed around Fort Williams. The beach ridges stand $2-3 \mathrm{~m}$ above the shore platform, are $20-40 \mathrm{~m}$ wide and up to $1 \mathrm{~km}$ long. We analyze the granulometric trend to define sequences and successive mobilizations of the material, with the perspective of find out a possible relation with climate variations during the Holocene.

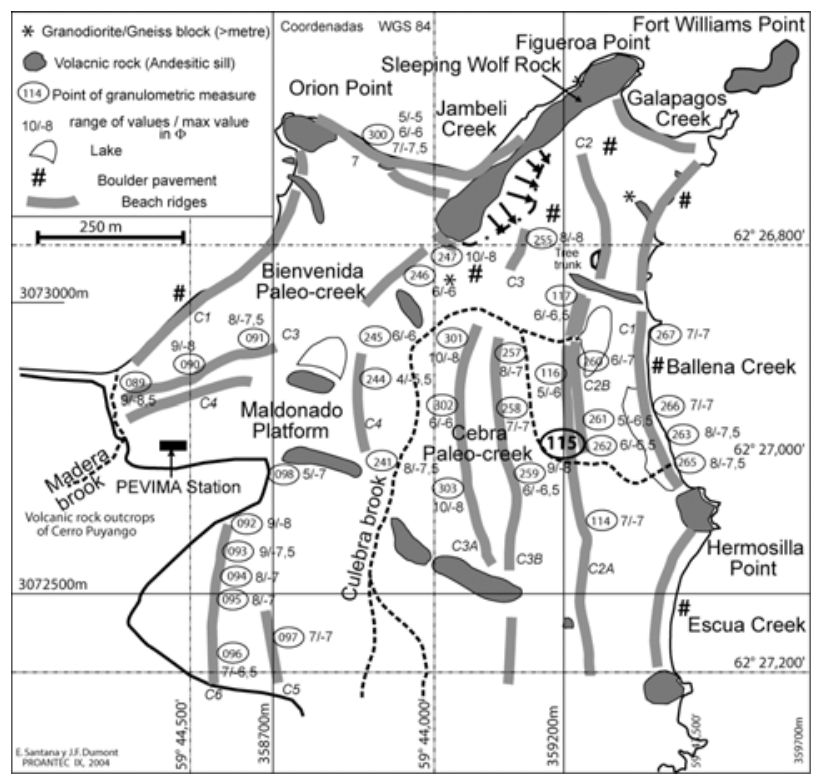

Figure 2. Map of beach ridges of Fort Williams Point.

\section{Methodology}

In order to analyze the granulometry of the pebble beach ridges we used the methods of Wolmann (1954) and Kellerhals and Bray (1971) as it has been synthesized in Malavoi (1986). In each study point we measured 50 pebbles using an abacus calibrated in $\Phi$, from -3 to $-8(8 \mathrm{~mm}$ to $256 \mathrm{~mm})$. The points of measurement are located on the top of the ridge, near the outer edge. The measurement points are spaced about $100 \mathrm{~m}$ apart. In total we made 2100 measurement from 39 points, 34 of them in Punta Fort Williams and the control points in Robert Island and Ambato Point. The coastline and the coastal morphology (ridge position and elevation, lake, drainage system and outcropping rocky relief) was leveled using GPS equipment. The geodesic reference base is in the Chilean Base Arturo Pratt, near Bascope Point, and a secondary base was set near the Ecuadorian Scientific Station Pedro Vicente Maldonado (PEVIMA). The elevation is measured amsl with a precision of $\pm 10 \mathrm{~cm}$.

\section{Granulometry analysis of beach ridges}

In this presentation we consider the central part of the ridges where the local effect of outcropping rocks and pebble supply from slope deposits or brooks are negligible (Santana and Dumont, 2006). Beach ridge C6 stands at an elevation of $13.5 \mathrm{~m}$ amsl. The range of pebble size extends from -3 to $-8 \Phi$, with the main class between -4.5 and $-6 \Phi$ (Fig. 2D). Both ridge ends are in contact with rock outcrops, but the proportion of large pebbles decreases from north to south. Beach ridge C5 crops out at an elevation of $11.5 \mathrm{~m}$ amsl, joining outcropping rocks to the south, but with a free end to the north. The range of size extends from -3.5 to $-7.5 \Phi$, with the main class at $-5.5 \Phi$ (Fig. 2D). Beach ridge C4 stands at an elevation of about $10 \mathrm{~m}$ amsl, outlining the Maldonado Platform and forming a tombolo to the north toward the Sleeping Wolf rock. The range of size extends from -3 to $-6.5 \Phi$, with the main class between -4 and $-5 \Phi$. The beach ridge C3A stands at an elevation of $7 \mathrm{~m}$ amsl. The range of size extends from -3 to $-8.5 \Phi$, with a main class at -5 to $-5.5 \Phi$ (Fig. 2E). Beach ridge $\mathrm{C} 3 \mathrm{~B}$ is located $50 \mathrm{~m}$ seaward from $\mathrm{C} 3 \mathrm{~A}$, at an elevation of $6 \mathrm{~m}$ amsl. The range of size extends from -3.5 to -7.5 $\Phi$, with a main class at -4 to $-4.5 \Phi$. Beach ridges $\mathrm{C} 2 \mathrm{~A}$ and $\mathrm{C} 2 \mathrm{~B}$ at $4-5 \mathrm{~m}$ amsl are close to each other, but well separated morphologically and continuous over more than $1 \mathrm{~km}$. Ridge C2A $(4.8 \mathrm{~m}$ amsl) presents a range of size from -3 to $-8.5 \Phi$, with a main group between -3.5 and $-6 \Phi$ and a main class at $-4.5 \Phi$ (Fig. 2F). The granulometry of ridge $\mathrm{C} 2 \mathrm{~B}$ is not very different, with a better sorting of coarse pebbles between -5 to $-6 \Phi$.

The beach ridge $\mathrm{C} 1$ is the present active ridge. A wide moss carpet without recent sediments separates the $\mathrm{C} 1$ ridge from $\mathrm{C} 2 \mathrm{~A}$ and $\mathrm{B}$. The active ridge presents a range of size from -3.5 to $-8 \Phi$, with a main class at $-5 \Phi$. Despite the relative homogeneity of the results, the comparison of the different curves presented in figure 2E-E-F suggests the occurrence of four main groups, successively C6-C5-C4, C3A-C3B, C2A-C2B and C1. The sequence analysis presented in figure 3 is based on the comparison of the range of $\Phi$ values (dispersion of the measures) and the main $\Phi$ value. The succession of pebble granulometry through a sequence suggests a better sorting of the material from the upper ridge of the sequence to the lower one.

\section{Discussion and conclusion}

Most of the granulometric curves give evidence of two main classes. There is no evidence of lithologic differences in the nearby outcropping volcanic rocks to explain these two classes. The presence of up to $3 \mathrm{~m}$ granodiorite and gneiss blocks suggests that at least part of the coarse fraction is allochtonous, and comes from a till cover that provides the sediment supply for the formation of the beach ridges, in particular in the areas far from any outcropping rock. 


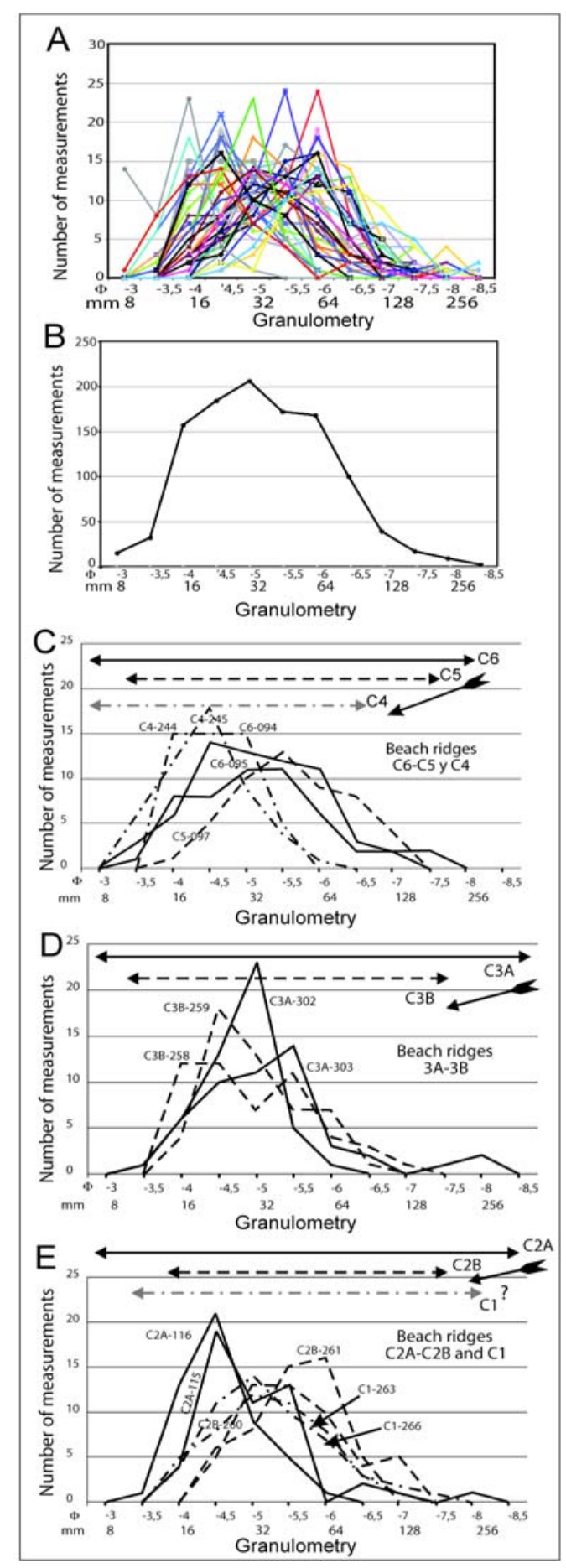

Figure 3. Granulometric curves. A: Individual curves. B: Total of all the measurements. C: Curves from ridges C6, $\mathrm{C} 5$ and $\mathrm{C} 4$. D: Curves from ridges $\mathrm{C} 3 \mathrm{~A}$ and $\mathrm{C} 3 \mathrm{~B}$. E: Curves from ridges $\mathrm{C} 2 \mathrm{~A}, \mathrm{C} 2 \mathrm{~B}$ and $\mathrm{C} 1$. The arrow shows the main trend of variation towards adjacent lower ridges. The number associated to the ridge (i.e. C2B-261) allows to identify the point of measurement on Fig. 2.
We made a rough estimation of the corresponding volumes of rock in study point 115 (Figure 4). We considered the spherical volume of the corresponding sizes of classes of $\Phi$. This estimation suggests that the pebbles over $-6 \Phi$ size correspond to a volume about 10 times higher than that of smaller pebbles. Considering that the coarser blocks including the gneiss and granodiorite comes from a till cover, the supply from this cover appear as very important relative to the local origin.

What is the element determining the successive sequences of beach ridges? Formation of a new ridge suggests new till available, that may be obtained by RSL fall. Variation of RSL fall may be due to tectonics or hydrostatic adjustment, or coastal processes (erosion, waves) during a relatively constant RSL fall. The high sequence C6-C5-C4 develops on a wider platform than the more recent sequences, and can be related to the end of the mid Holocene RSL highstand identified by Bentley et al. (2005b)(2005a).

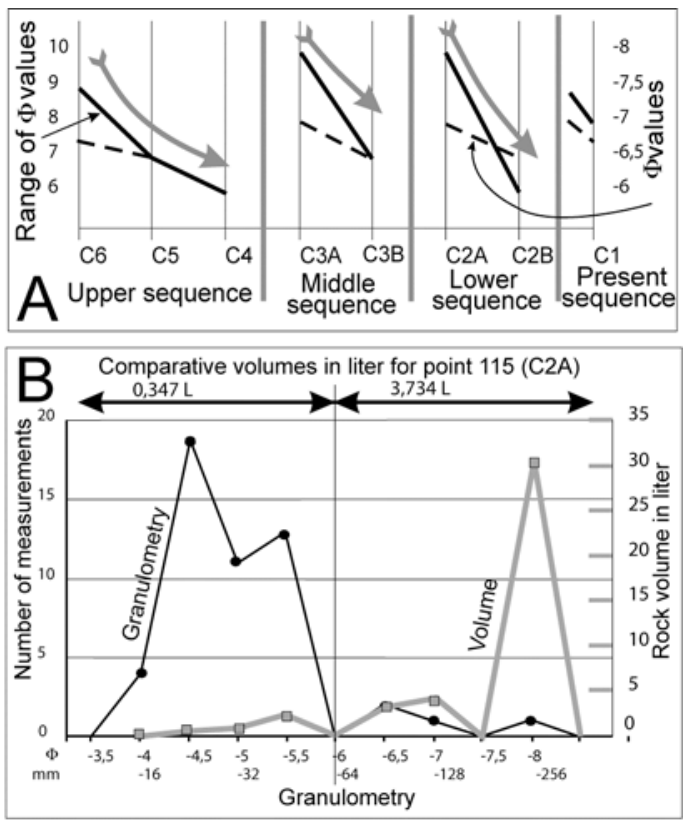

Figure 4. Variation of the range of $\Phi$ values considering the number of half $\Phi$ classes (dispersion) and main granulometric class, giving evidence of successive sequences of mobilization of pebbles.

The presence of pavement surfaces and boulder accumulation between the sequences of beach ridge (Fib. $2 \mathrm{~A}$ ) indicates that the beach ridge construction was a discontinuous process, with periods lacking totally of ridge construction. Such morphologies described by Hansom (1983) from northern Antarctic Peninsula are interpreted as the effect of icebergs pushed onto the shore platform. Pavement area extends over several tens of meters up to more than one hundred meter, generally 
elongated orthogonally to the coastline, and made of closely jointed decimeter size pavement elements with the upper surface flattened and sometimes striated by pressure and friction. Boulder up to $3 \mathrm{~m}$ are pushed and accumulated outside of the pavement surfaces by the movement of icebergs. The pavement areas cover shallow depressions of the coastal platform, and rock basement crops out in several places between the ridges.

Pavement formation by iceberg and pebble beach ridge accumulation represent evidently opposed processes, and may be considered as seasonal (winter/summer) coastal processes. However the spacing of beach ridges suggests a lower frequency of pavement/beach ridge formation, possibly determined by temperature oscillations during the Holocene: colder periods favor total winter freeze or the English Strait and persistency of icebergs on the shore during summer, and warmer periods like the present one allow only partial winter freeze of the sea and about no significant iceberg on the shore at the end of winter and during summer. This interpretation suggests that sequences of beach ridge construction registered ocean-atmosphere temperature variability during the Holocene.

We lack presently of precise dating of the beach ridge sequences to suggest a time scale of late Holocene climate variability. However warm and humid conditions are registered between 1450 and $1700{ }^{14} \mathrm{C}$ yr B.P. in King George Island (Yoo et al., 2006), that can hypothetically be correlated with beach ridge sequence C3. Late neoglacial moraines in the Southern Andes in the period 1220-1460 AD and subsequently in the 1620s $\mathrm{AD}$ (Kilian et al., 2007) may be correlated with the period of boulder pavement on the shore of the Antarctic Peninsula after the $\mathrm{C} 2$ ridge, and before the formation of the present active ridge. Record of Holocene rainfall in southern Chile presents bands of variability at ca. 900 and $1500 \mathrm{yr}$ (Lamy et al., 2001), that may fit with the C2 beach ridge construction. The active construction of the present $\mathrm{C} 1$ beach ridge and the lack of iceberg on the shore at least during the last decade may be correlated with the present global rising temperature.

Acknowledgement. This study is part of the scientific activity of the expeditions PROANTEC VIII and IX directed by INOCAR. We thank the Ecuadorian Antarctic Institute (INAE) for its support. We are grateful to the Chief of the Chilean Base Arturo Pratt for complementary information during recent winters. J-L. Guillot helped for pebble and gravel sedimentology. The final copy benefited of comments from R. Pallas, and we acknowledge the co-editor Tom Naish.

\section{References}

Araya, R. and F. Hervé (1966), Estudio geomorfológico y geológico en las Islas Shetland del Sur, Antártica. Publicaciones del Instituto Antártico Chileno, 8: 76.

Bentley, M. J., D. A. Hodgson, J. A. Smith, and N. J. Cox (2005a), Relative sea level curves for the South Shetland Islands and Marguerite Bay, Antarctic Peninsula. Quarternary Science Reviews, 24: 1203-1216.

Bentley, M. J., Hodgson, D. A., Sugden, D. E., Roberts, S. J., Smith, J. A., Leng, M. J. and C. Bryant (2005b), Early Holocene retreat of the George VI Ice Shelf, Antarctic Peninsula. Geology, 33: 173-176.

Berkman, P. A. and S. L. Forman (1996), Pre-bomb radiocarbon and the reservoir correction for calcareous marine species in the Southern Ocean. Geophysical Research Letters, 23: 363-366.

Clapperton, C. M. and D. E Sugden (1988), Holocene glacier fluctuation in South America and Antarctica. Quaternary Science Reviews, 7: 185-198.

Curl, J. (1980), A glacial history of the South Shetland Islands, Antarctica, Ohio State University, Columbus, $\mathrm{OH}$.

Dumont, J. F., Santana, E., Hervé, F. and C. Zapata (2006), Regional structures and geodynamic evolution of North Greenwich (Fort Williams Point) and Dee Islands, South Shetland Islands. In: D.D. Fütterer D. K, Kleinsscmidt G, Tessensohn F. (Editor), Antarctica: contribution to global earth sciences. Springer-Verlag, Berlin Heidelberg, New York, pp. 255-260.

Hansom, J. D. (1983), Ice formed intertidal boulder pavement in the sub-antarctic. Journal of Sedimentary Petrography, 53(1): 135-145.

John, B. S. and D. E. Sugden (1971), Raised marine features and phases of glaciation in the South Shetland Islands. British Antarctic Survey Bulletin, 24: 45-111.

Pallas, R., James, T. S., Sabat, F., Vilaplana, J. M. and D. R. Grant (1997), Holocene uplift in the South Shetland Islands: Evaluation of Tectonics and Glacio-Isostasy. The Antarctic Region: Geological Evolution and Processes: 861-868.

Santana, E. and J. F. Dumont (2006), Características granulométricas de los cordones litorales en Punta Fort Williams, Isla Greenwich, Península Antártica Revista Tecnológica ESPOL, 19(1): 161-172.

Santana, E. and J. F. Dumont (2002), Geología de los alrededores de la Estación Ecuatoriana Pedro Vicente Maldonado (Isla Greenwich) e Isla Dee, Península Antártica. Acta Antártica Ecuatoriana, 1: 7-32.

Santana, E. and J. F. Dumont (2003), Geology in the vicinity of the Ecuadorian Scientific Station Pedro Vicente Maldonado (Greenwich and Dee Islands, Antarctic Peninsula), 9th International Symposium on Antarctic Earth Sciences, Potsdam.

Smellie, J. L., Pallas, R., Sabat, F., and X. Zheng (1996), Age and correlation of volcanism in central Livingston Island, South Shetland Islands: $\mathrm{K}-\mathrm{Ar}$ and geochemical constraints. Journal of South American Earth Sciences, 9(3/4): 265-272.

Smellie, J. L., Pankurst, R. J., Thomson, M. R. A. and Davies, R. E. S. (1984), The geology of the South Shetland Islands: VI, stratigraphy, geochemistry and evolution. 87, British Antarctic Survey. 